\title{
Reframing commitment in authentic leadership: Untangling relationship-outcome processes
}

\author{
Andrei A. Lux ${ }^{1 *}$ (D), Steven L. Grover ${ }^{2}$ and Stephen T. T. Teo ${ }^{1}$ \\ ${ }^{1}$ Edith Cowan University, 270 Joondalup Drive, Perth WA 6027, Australia and ${ }^{2}$ Macquarie University, 4 Eastern Road, \\ Sydney NSW 2113, Australia \\ *Corresponding author. Email: a.lux@ecu.edu.au
}

(Received 6 January 2019; accepted 5 November 2019; first published online 6 December 2019)

\begin{abstract}
Affective organizational commitment is theorized and empirically tested as a key mediator between authentic leadership and desirable employee outcomes. The results of a two-wave survey of 830 business people in Australia support a serial mediation model of authentic leadership efficacy. Followers' perceptions of authentic leadership behavior influence their personal identification and affect-based trust in the leader, which in turn are mediated by affective organizational commitment to positively influence their work engagement and job satisfaction. These findings reinforce previous work that positions personal identification and affect-based trust as the two primary mediating mechanisms of authentic leadership. This paper extends prior research by demonstrating the important role of followers' affective bonds with their organization in the operation of authentic leadership, moving beyond the dyad in our understanding of follower outcomes.
\end{abstract}

Keywords: Authentic leadership; personal identification; trust; organizational commitment; work engagement; job satisfaction

\section{Introduction}

Authentic leadership is a dominant theory of contemporary business leadership, gripping scholars and practitioners alike and enjoying ample research attention (for a recent review, see Iszatt-White \& Kempster, 2018). Authentic leaders 'are guided by sound moral convictions and act in concordance with their deeply held values, even under pressure; they are keenly aware of their views, strengths, and weaknesses, and strive to understand how their leadership impacts others' (Peus, Wesche, Streicher, Braun, \& Frey, 2012, p. 332). Authentic leadership affects a host of positive organizational outcomes (for a meta-analysis, see Banks, McCauley, Gardner, \& Guler, 2016), and yet questions remain about how the construct produces these desirable effects.

Prior research shows that followers' personal identification with leaders and affect-based trust mediates the relations between authentic leadership and employee outcomes (Alilyyani, Wong, \& Cummings, 2018), because followers have stronger and more positive relationships with leaders with whom they share values and trust. Authentic leadership also has broader work- or job-related outcomes such as engagement and satisfaction. The influence of authentic leadership, however, goes beyond the leader-follower dynamic to also affect followers' experiences within organizations. Followers' affective commitment to their organization is the missing link between the relational mechanisms and employee outcomes. More precisely, we theorize that through increased personal identification and trust, authentic leadership positively influences employees'

(c) Cambridge University Press and Australian and New Zealand Academy of Management 2019. This is an Open Access article, distributed under the terms of the Creative Commons Attribution licence (http://creativecommons.org/licenses/by/4.0/), which permits unrestricted re-use, distribution, and reproduction in any medium, provided the original work is properly cited. 


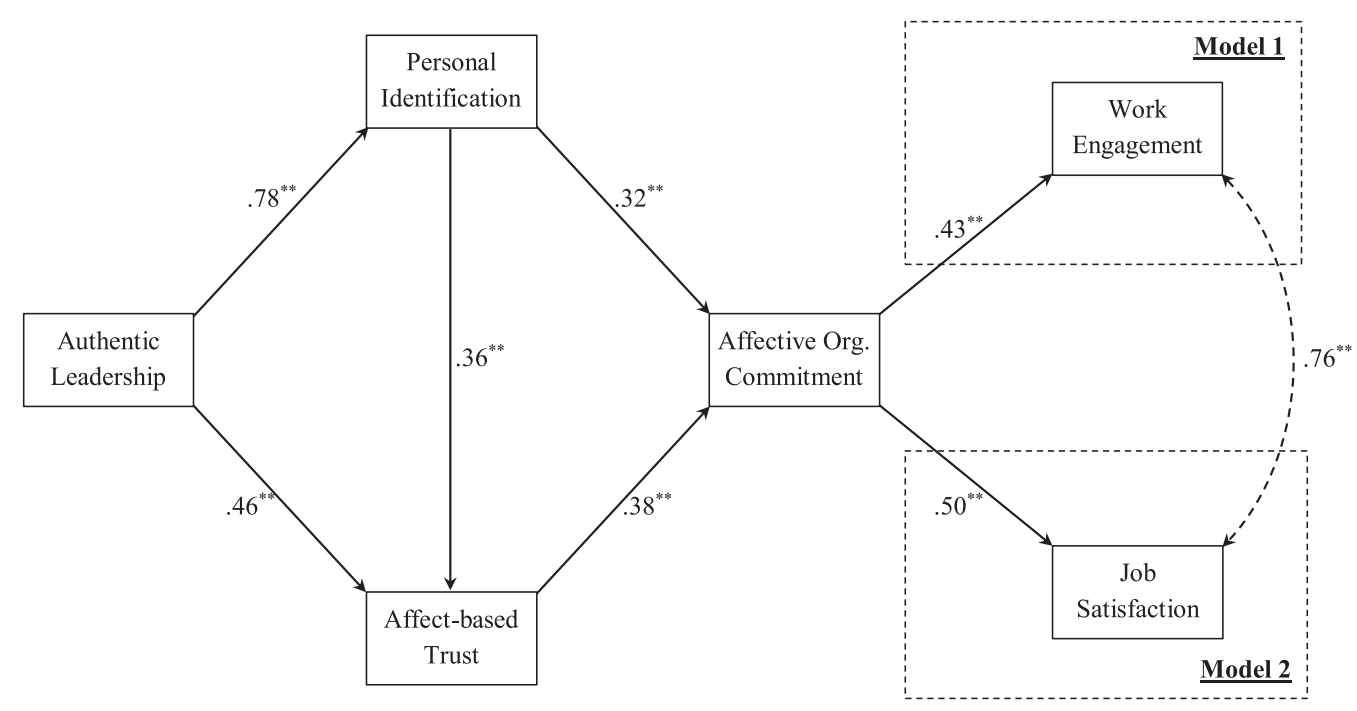

Figure 1. Serial multiple mediation analysis of authentic leadership processes.

Note. $N=281,{ }^{\star} p<.05,{ }^{\star \star} p<.001$. Non-significant $(p>.05)$ mediation paths are suppressed for clarity. Dotted path indicates correlation.

affective commitment to the organization, which in turn promotes work engagement and job satisfaction (Banks et al., 2016; Hoch, Bommer, Dulebohn, \& Wu, 2018). As the nature of work becomes more transient (Klein, Molloy, \& Brinsfield, 2012), understanding how employees' emotional association with an organization affects their experiences of leadership, engagement, and satisfaction is more important now than ever before.

The present study therefore examines the role of followers' affective attachment to their organization in the processes between followers' experience of authentic leadership behavior and their work-related outcomes. We contribute to the literature by demonstrating that affective organizational commitment connects known relational mediators with desirable follower outcomes. We thereby explain how authentic leadership influences employees' work engagement and job satisfaction through a sequential mediation process, and provide empirical evidence to support these relations. Figure 1 illustrates our theoretical framework and we explain the specific linkages in the following sections.

\section{Hypothesis Development}

\section{Personal identification}

Personal identification is defined as a 'perceived oneness with another individual' (for a review, see Ashforth, Schinoff, \& Rogers, 2016, p. 28). Kark and Shamir (2002) explain that personal identification is the 'process whereby [an] individual's beliefs about a person become selfreferential or self-defining' (p. 70). Personal identification is distinct from the related concepts of social and relational identification. Social identification is derived from social identity theory (Tajfel \& Turner, 1986) and refers to the attributes that reflect group membership; for example, employees may come to identify with their team or organization. Relational identification is the process whereby individuals' self-concept is derived from their role relationships with significant others (Brewer \& Gardner, 1996), such as how employees may define themselves as followers of a leader. Personal identification, however, refers to the process whereby individuals come to identify with the distinct attributes of a specific person - their leader in this case - and therefore captures the value congruence between leaders and followers (Ashforth, Schinoff, \& Rogers, 2016). 
Followers more readily identify with authentic leaders because their core values are accessible so that followers can form self-defining relationships with them. In contrast, less authentic leaders at least partly mask their values, which act as a barrier to the personal identification process. Leadership has a stronger impact on followers' outcomes when they identify with their leader (Campbell, Trapnell, Heine, Katz, Lavallee, \& Lehman, 1996; Howell \& Shamir, 2005; Kark, Shamir, \& Chen, 2003; Peterlin, Penger, \& Dimovski, 2009). As followers come to identify with their authentic leader, they begin to strive toward 'goals that are, in part, derived from and congruent with those of the leader' (Avolio \& Gardner, 2005, pp. 326-327). Social identity theory suggests that leaders are representative of the wider organization to their followers (Kalshoven \& Den Hartog, 2009; Van Knippenberg, 2011). Therefore, as followers come to personally identify with their authentic leader, they then begin to form more positive affective connections to the organization as whole. Hence:

Hypothesis 1: Followers' personal identification with their leader mediates the relationship between their perceptions of authentic leadership and their affective organizational commitment.

\section{Interpersonal trust}

Trust consistently emerges as an important factor in the authentic leadership relationship (Gardner, Avolio, Luthans, May, \& Walumbwa, 2005; Hasel \& Grover, 2017; Wong \& Cummings, 2009; Wong, Spence-Laschinger, \& Cummings, 2010). Rousseau, Sitkin, Burt, and Camerer (1998) define trust as 'the intention to accept vulnerability based upon positive expectations of the intentions or behaviors of another' (p. 395). Trust is therefore built upon a foundation of confidence in another person's 'competence and willingness to act in a fair, ethical, and predictable manner' (Nyhan \& Marlowe, 1997, p. 616): the belief that their actions will 'be beneficial, or at least not detrimental, to one's interests' (Robinson, 1996, p. 576). The relationships cultivated through authentic leadership are characterized by candor and behavioral integrity. Based on the ability, benevolence, and integrity framework of trust (Mayer, Davis, \& Schoorman, 1995), followers are therefore more willing to make themselves vulnerable to authentic leaders with transparent goals and values, which is relatively safe as compared to less authentic leaders.

Research shows that authentic leadership relates positively to trust (Gardner et al., 2005; Wong \& Cummings, 2009; Wong, Spence-Laschinger, \& Cummings, 2010), and Dirks and Ferrin (2002) show in their meta-analysis that followers' trust in leadership is positively related to job satisfaction, organizational commitment, and work performance. Relationship-oriented leadership theories - such as authentic leadership - are more strongly associated with affective trust, rather than cognitive trust (Colquitt, Baer, Long, \& Halvorsen-Ganepola, 2014; Hasel \& Grover, 2017). Cognitive trust is an instrumental pragmatism similar to the notion of reciprocity, whereas affective trust emanates from a positive personal relationship such as that wrought from the authentic expression of shared values. Based on social identity theory, leaders serve as prototypical representatives of the organization (Kalshoven \& Den Hartog, 2009; Van Knippenberg, 2011). When employees feel that they cannot trust their leaders, they attempt to reduce their vulnerability by psychologically distancing themselves from the organization (Nyhan, 1999). Therefore, authentic leaders who have trusting relationships with their followers evoke a more positive emotional connection to the organization itself. Thus, we hypothesize that:

Hypothesis 2: Followers' affect-based trust in their leader mediates the relations between their perceptions of authentic leadership and their affective organizational commitment.

Followers' personal identification and affect-based trust relate because trust is based in part on behavioral consistency (Butler, 1991; Nyhan \& Marlowe, 1997). As employees come to know and 
personally identify with their leader, the leader's consistent actions make more sense and thereby produce increased trust. The open and honest nature of authentic leadership relationships builds followers' confidence in the leader's actions and intentions, which likewise promotes interpersonal trust. Therefore, authentic leadership behavior directly influences followers' trust in the leader (Clapp-Smith, Vogelgesang, \& Avey, 2009), while followers' personal identification with their leader mediates the relation between their perceptions of authentic leadership and their affect-based trust in the leader. Existing empirical studies support this partial mediation effect on trust (Fox, Gong, \& Attoh, 2015; Wong, Spence-Laschinger, \& Cummings, 2010). Congruent with their results, we propose that followers' personal identification functions as a mediating mechanism through which authentic leadership produces increased follower trust.

Hypothesis 3: Followers' personal identification with their leader partially mediates the relationship between followers' perceptions of authentic leadership and their affect-based trust in the leader.

We thereby position followers' affect-based trust as the second sequential mediating mechanism that connects authentic leadership to positive follower outcomes. The following section explores the concept of commitment to theorizing its operation at the center of authentic leadership processes.

\section{Organizational commitment}

Businesses require a stable workforce in order to be effective and employees who are unlikely to leave an organization are conceived of as being committed (Allen \& Meyer, 1990). However, merely maintaining workforce continuity is inadequate because "what employees do on the job is as important, or more important, than whether they remain' (Allen \& Meyer, 1990, p. 15): employees must also be willing to go beyond their basic role requirements in order to consistently deliver superior performance (Katz, 1964; Organ, Podsakoff, \& MacKenzie, 2005). Accordingly, Buchanan (1974) focuses instead on workers' dedication when defining organizational commitment as 'a partisan, affective attachment to the goals and values of the organization, to one's role in relation to the goals and values, and to the organization for its own sake, apart from its purely instrumental worth' (p. 533).

Allen and Meyer (1990) isolate three different kinds of commitment: continuance, normative, and affective. Individuals with continuance commitment are conscious of the costs associated with leaving and therefore need to maintain employment; those with normative commitment perceive an obligation to stay because they ought to; and those with affective organizational commitment are emotionally attached to their organization and remain because they want to (Allen \& Meyer, 1990). The kind of commitment experienced by employees affects the extent and quality of their contribution to the overall effectiveness of the organization, with those that want to belong adding more value than those who either need to or who feel obligated to (Meyer \& Allen, 1991). Empirical studies find employees' affective organizational commitment to be positively related to desirable organizational outcomes, such as reduced turnover (Meyer \& Allen, 1991), citizenship (Shore \& Wayne, 1993), service quality (Malhotra \& Mukherjee, 2004), and performance (Meyer, Paunonen, Gellatly, Goffin, \& Jackson, 1989). In contrast, continuance and normative commitment are either unrelated to or negatively correlated with performance ratings (Malhotra \& Mukherjee, 2004; Meyer et al., 1989). Klein, Molloy, and Brinsfield (2012) therefore exclude employees' acquiescent or instrumental association with an organization to redefine commitment as an innately affective bond that is characterized by 'volition, dedication, and responsibility' (p. 134).

Social identity theory suggests that followers who form positive workplace relationships with their supervisors are then more likely to develop stronger emotional attachments to the wider organization (Kalshoven \& Den Hartog, 2009; Van Knippenberg, 2011). Indeed, previous studies 
report positive relations between followers' perceptions of authentic leadership and their affective organizational commitment (e.g. Giallonardo, Wong, \& Iwasiw, 2010; Jensen \& Luthans, 2006; Peus et al., 2012; Walumbwa, Avolio, Gardner, Wernsing, \& Peterson, 2008; Wong, Spence-Laschinger, \& Cummings, 2010). The influence of authentic leadership, thus, goes beyond the leader-follower dynamic to affect followers' experiences within the organization. Yet studying organizational commitment only as a terminal product of good leadership precludes an understanding of how employees' emotional association with their organization shapes their work-related outcomes.

Followers' affective attachment to the organization is the missing link between the known relational mechanisms and followers' desirable organizational outcomes in authentic leadership theory. More precisely, we propose that through increased personal identification and trust, authentic leadership positively influences employees' affective commitment to the organization, which in turn promotes work engagement and job satisfaction (Banks et al., 2016; Hoch et al., 2018). Affective commitment thereby serves as the key mediating link between the relational authentic leadership processes and the desirable follower outcomes. Prior studies likewise position followers' affective organizational commitment as an important antecedent of their work engagement and job satisfaction (Meyer, Stanley, Herscovitch, \& Topolnytsky, 2002; Poon, 2013). Therefore, we propose that:

Hypothesis 4: Followers' affective organizational commitment mediates the relationship between their personal identification with their leader and their work engagement (Hypothesis $4 \mathrm{a}$ ) and job satisfaction (Hypothesis 4b).

Hypothesis 5: Followers' affective organizational commitment mediates the relationship between their affect-based trust in their leader and their work engagement (Hypothesis $5 \mathrm{a}$ ) and job satisfaction (Hypothesis 5b).

In summary, we argue that authentic leadership delivers positive follower outcomes through a sequential mediation process of personal identification, affect-based trust, and affective organizational commitment. These three mechanisms produce increased work engagement and job satisfaction, which have a reciprocal causal relationship and together serve as key metrics of leadership efficacy. See Figure 1 for a graphical representation of our theoretical framework.

\section{Method}

We distributed web-based surveys to a sample of employed business-people in Australia. Data collection was split into two waves several weeks apart to mitigate potential common method bias (Podsakoff, MacKenzie, Lee, \& Podsakoff, 2003). The first survey wave collected authentic leadership and personal identification responses while the second wave collected the remaining latent variables. The following sections discuss the methods used to test our hypotheses and address in turn each of the scales selected for this study, before moving on to present the analyses and results.

\section{Sample}

We approached PureProfile, an Australian-based research company, to distribute surveys to their panel members. Such a recruitment strategy is common in the management literature (see Pugh, Groth, \& Hennig-Thurau, 2011; Teo, Pick, Xerri, \& Newton, 2016). An anonymous survey link was emailed to panel members who met our selection criteria: employed adults living in Australia who had an immediate supervisor at work and were not self-employed. We take a position-based view of leadership and operationalized respondents' supervisor to be their leader in our sample 
(Grint, Jones, \& Holt, 2017). No specific industry or organization type was targeted so that the results could be generalized across a broad range of workplaces.

A total of 1710 participants were contacted by PureProfile to complete the online survey. Some of the participants were excluded because they did not meet the selection criteria (e.g. 24 were not living in Australia; 193 were not currently employed; 138 were self-employed; 307 had no immediate supervisor at work; 216 completed the survey in under $6 \mathrm{~min}$; and two participants returned invalid responses). In total, we retained 830 responses ( $48.5 \%$ response rate) to the wave one surveys. After a one week interval, 281 of these respondents completed the wave two surveys (33.9\%). The response rates were at acceptable levels (Ribisl, Walton, Mowbray, Luke, Davidson, \& Bootsmiller, 1996) and yielded sufficient data for mediation analysis and regressive structural equation modeling (Fritz \& MacKinnon, 2007; Wolf, Harrington, Clark, \& Miller, 2013).

The average age for the larger sample was 46.5 years old $(\mathrm{SD}=11.8)$ and $63.1 \%$ of the respondents were female. The majority of respondents were born in Australia (71.3\%), spent their first five formative years there (72.8\%), and lived in Australia at the time of the survey (95.4\%). On average, the respondents had spent over $85 \%$ of their lives in their current country of residence and $87.2 \%$ spoke English as their first language. Approximately three quarters had attained education beyond the secondary school level, including trade certificates (23.4\%) and bachelor degrees (33.4\%). Most were employed full-time (64.9\%) for large organizations $(52.7 \%$, with 250 employees or more). No one particular industry dominated the sample and respondents were engaged across a wide variety of sectors, including professional services (16.7\%), government $(14.2 \%)$, education (13.9\%), health $(11.2 \%)$, retail $(8.9 \%)$, etc. Respondents had spent an average of 9.9 years $(\mathrm{SD}=9.4)$ at their current place of employment and had worked for 4.2 years $(\mathrm{SD}=4.9)$ with their current supervisor. No substantive differences were observed in the demographic composition between the respondents in wave one and the sub-sample who also completed wave two.

\section{Measures}

The surveys contained a total of 52 scale items comprised of the Authentic Leadership Inventory (ALI; Neider, \& Schriesheim, 2011), the Personal Identification with Leader Scale (PILS) adapted from Kark, Shamir, and Chen (2003), a measure of Affect-based Trust (ABT; McAllister, 1995), the Affective Commitment Scale (ACS; Allen \& Meyer, 1990), the Utrecht Work Engagement Scale-9 (UWES-9; Schaufeli, Bakker, \& Salanova, 2006), and the Brief Index of Affective Job Satisfaction (BIAJS; Thompson \& Phua, 2012). The following sections discuss each of these scales in greater detail, presenting the rationale for their inclusion before moving on to consider control variables and the impact of common method variance.

\section{Authentic leadership}

The theoretical construct of authentic leadership was first operationalized by Walumbwa et al., (2008) through the Authentic Leadership Questionnaire (ALQ). This instrument treats authentic leadership as a higher-order latent factor represented by four dimensions, as per the dominant conceptualization in the academic literature (Avolio, Walumbwa, \& Weber, 2009). The ALQ is thus advantaged by a sound theoretical foundation, which is an essential step toward the development of valid and reliable psychometric measures (Hinkin, 1995). However, the original content validation process relied extensively on a small sample of subject matter experts and the reported CFA results indicated that the best-fitting empirical model did not match the theoretical framework. These discrepancies raise concerns over the integrity of such subjective methods and a rigorous quantitative approach toward scale development is emerging (see Hinkin \& Tracey, 1999).

In order to address the concerns over the ALQ, Neider and Schriesheim (2011) used the same well-established conceptual foundation and developed a new scale called the ALI. They used an ANOVA-based approach to assess content validity, thereby reducing the impact of subjectivity on 
item selection and validity assessment (Schriesheim \& Cogliser, 2009; Schriesheim, Cogliser, Scandura, Lankau, \& Powers, 1999). While both the ALQ and the ALI share an identical theoretical basis, the more rigorous scale development procedures implemented in the formation of the ALI distinguish it as the preferred measure. Therefore, the 16-item ALI was used in the present study to capture followers' perceptions of authentic leadership.

\section{Personal identification}

Kark, Shamir, and Chen (2003) created a social identification scale as an amalgam of previous work by Mael and Ashforth (1992) and Shamir, Zakay, Breinin, and Popper (1998): its purpose was to capture employees' identification with their branch or department. Kark and colleagues then rephrased these items to make a similar scale which measured employees' personal identification with their branch manager. The resulting 10-item scale demonstrated reliability $(\alpha=.93)$ and its construct validity was assessed through confirmatory factor analysis (CFA) (Kark, Shamir, \& Chen, 2003). The full scale was provided by the authors upon request and without restriction. To fit the needs of the present work, the original wording was amended to direct the questions toward followers' 'immediate supervisor' and the resulting instrument was called the PILS. See Appendix A for a full list of PILS items.

\section{Affect-based trust}

McAllister (1995) differentiates between cognition- and affect-based trust, the latter demonstrating positive relations with organizational outcomes and leader-follower interactions. Cognition-based trust is generally associated with mutually beneficial exchanges (reciprocity), whereas affect-based trust 'most explicitly evokes a relationship and... sentiments like commitment and intrinsic significance'(Colquitt et al., 2014, p. 5). Hence, ABT was selected as most suitable for investigating the operation of authentic leader-follower relations. McAllister (1995) followed a rigorous scale development methodology in creating a five-item measure of ABT, and all five items were included in the present study.

\section{Affective commitment}

Meyer and Allen (1984) developed the eight-item ACS to measure affective organizational commitment at the individual level. Later studies have established that this unidimensional scale is both valid and reliable with internal consistency estimates between .84 and .88 (Allen \& Meyer, 1990; McGee \& Ford, 1987; Meyer, Allen, \& Gellatly, 1990; Meyer et al., 1989). More recently, Malhotra and Mukherjee (2004) used CFA with Varimax rotation to reconfirm that the items were loading as expected and added support for the discriminant validity of the ACS. Thus, all eight ACS items were used in the present study to gauge followers' affective organizational commitment.

\section{Work engagement}

Employee work engagement is defined as 'a positive work-related state of fulfillment that is characterized by vigor, dedication, and absorption' (Schaufeli, Bakker, \& Salanova, 2006, p. 701). It has featured in a number of empirical authentic leadership studies (see Gardner, Cogliser, Davis, \& Dickens, 2011) and constitutes an important follower outcome metric for leadership research. Schaufeli, Bakker, and Salanova (2006) reanalyzed earlier data to reduce their original Utrecht Work Engagement Scale from 17 items to nine items (UWES-9), which likewise demonstrated acceptable psychometric properties without sacrificing validity or reliability over the original.

\section{Job satisfaction}

The construct of job satisfaction appears repeatedly across business research over the last 75 years, resulting in a 'problematically large' (p. 276) array of measurement scales (Thompson \& Phua, 2012). Whitman, Van Rooy, and Viswesvaran (2010) concluded in their meta-analysis that the 
majority of researchers used 'ad hoc measures' (p. 55) that lack validity. Moreover, this nebulous variety of scales makes it difficult to draw direct comparisons between studies and hinders the incremental development of knowledge in the field (O'Connor, Peters, \& Gordon, 1978). To address this issue, Thompson and Phua (2012) have developed a concise, theoretically grounded, and psychometrically valid 4-item scale called the BIAJS. As such, the BIAJS was well-suited to capturing followers' job satisfaction in the present study and all four items were included in their original configuration.

\section{Control variables}

We controlled for social desirability and several work-related demographic factors. Social desirability captures the tendency for respondents to inflate self-reported survey outcomes, and must therefore be controlled during hypothesis testing (Van de Mortel, 2008). We used a 13-item scale developed by Reynolds (1982) to measure social desirability. In addition, we controlled for: (a) the industry that respondents are employed in, since leadership efficacy varies between sectors (Hooijberg \& Choi, 2001); (b) respondents' employment status (i.e. full-time, part-time, or casual), which can determine their job satisfaction and organizational commitment (Thorsteinson, 2003); (c) the size of the organization that they work for, which affects leadership outcomes (e.g. Koene, Vogelaar, \& Soeters, 2002; Vaccaro, Jansen, Van Den Bosch, \& Volberda, 2012); and (d) how long they have been working with their current supervisor, which is a predictor of trust (Perry, 2004). These variables were included as covariates in the initial serial mediation analyses because they have known correlations to the focal study constructs and parsing out their variance generates a more robust representation of the relations between the latent constructs of interest (for a review, see Becker, 2005). We next consider the phenomenon of common method variance before moving on to present our analyses and results.

\section{Common method variance}

The present work addresses relations between different employee work attitudes, which must be measured at the individual level. Hence, it is impossible to control for common method variance (CMV) by collecting predictor and criterion data from different sources (Podsakoff et al., 2003). While common method variance cannot be eliminated, we follow the Podsakoff et al., (2003) procedures to mitigate its impact. As such, we address common method issues proactively in the present study using two techniques. First, by splitting the survey into two stages we separate the measurement of predictor and criterion variables with a temporal delay between data points: collecting independent variables in the first survey wave and then dependent variables two weeks later via a follow-up survey. Second, by using construct-validated scales wherever possible to maximize the likelihood that responses are indicative of the distinct latent constructs, rather than an underlying common method variance (Podsakoff et al., 2003).

Although the debates around common method variance are still ongoing (for reviews, see Conway \& Lance, 2010; Richardson, Simmering, \& Sturman, 2009), the potential implications for validity 'cannot be ignored' (Ashkanasy, 2008, p. 264). Therefore, two additional post-hoc statistical techniques were used to ascertain whether CMV issues were present in the data. The first procedure involves conducting an exploratory factor analysis with all of the construct-level variable items, to see if 'either (a) a single factor will emerge from the factor analysis or (b) one general factor will account for the majority of covariance among the measures' (Podsakoff et al., 2003 , p. 889). The second procedure uses an unmeasured latent variable with CFA across all construct items to estimate CMV effects: Harman's single-factor test (Williams \& Anderson, 1994; Williams, Edwards, \& Vandenberg, 2003).

Results of the unrotated principal component factor analysis revealed four distinct factors with eigenvalues greater than 1.0, rather than a single factor. Interpreting the Varimax rotated solution, these four factors together accounted for $69.0 \%$ of the total variance and the first (largest) 
factor did not account for a majority of the variance (29.1\%). Thus, one general factor was not apparent. Furthermore, the CFA showed that the single-factor model did not fit the data well $\left(\chi^{2} / d f(723)=6.85, p=.00, \mathrm{GFI}=.42 ; \mathrm{CFI}=.59 ; \mathrm{NFI}=.56\right.$; RMSEA $\left.=.15\right)$. These results do not preclude the possibility of CMV issues, but rather suggest that CMV is not of overriding concern and is therefore unlikely to inhibit the interpretations of later tests. Hence, no post-hoc CMV correction techniques were included during subsequent analyses.

\section{Analysis and results}

Reliability analyses using Cronbach's coefficient alpha and composite reliability (CR) showed that all of the measures exceeded the .70 acceptable thresholds for both indices (DeVellis, 2012; Hair, Black, Babin, \& Anderson, 2010; Nunnally, 1978), confirming that the scales are sufficiently reliable (see Tables 1 and 2 for the results). The average variance extracted (AVE) scores were all above .50 , demonstrating that the items comprising each instrument have convergent validity (Hair et al., 2010).

We next established discriminant validity using the Fornell and Larcker (1981) test with measurement error-adjusted inter-construct correlations derived from a CFA. The square root of the AVE score for each latent construct was higher than the absolute correlation with any other latent variable, thereby confirming the discriminant validity of each scale. The measures used in the present study were thus sufficiently reliable, internally consistent, and distinct to proceed with subsequent analysis. The one exception was work engagement, which had an AVE square root of .75 and yet correlated at .88 with job satisfaction, suggesting some empirical overlap. This outcome supports our earlier arguments that respondents' work engagement and job satisfaction have a reciprocal causal relationship. Including both constructs in a linear causal model would introduce multicollinearity. We therefore kept the two constructs separate as distinct dependent variables in our initial mediation models, and then covaried them during scanning electron microscopy (SEM) analysis.

Before testing our hypothesized seven-factor model (including social desirability), we assessed the measurement model fit by comparing it to several nested measurement models, collapsing our seven-factor solution down to a single-factor model (see Table 3). We used IBM AMOS v24 to conduct multiple CFAs. The results indicate that the hypothesized seven-factor solution is the best fit to the data $\left(\chi^{2} / d f(702)=1.67, p=.00, \mathrm{GFI}=.83\right.$; CFI $=.96$; NFI $=.90$; RMSEA $\left.=.05\right)$, and it is therefore appropriate to proceed with hypothesis testing.

Mediation analysis was conducted with Hayes (2013) PROCESS macro using the Preacher and Hayes (2004) bootstrapping method. The technique involves 'taking a large number of samples... from the data, sampling with replacement, and computing the indirect effect in each sample' (Preacher \& Hayes, 2004, p. 722). A confidence interval is then calculated at 95\% and should zero falls outside of this interval the indirect effect is considered significantly different from zero at $p<.05$ (two-tailed). The PROCESS macro automates this sequence and can be accessed through a custom SPSS dialog. We used serial mediation Model 6 to test our hypotheses (for a guide, see Hayes, 2013, pp. 143-156). All of the tests were run with 10,000 bias-corrected bootstrap samples, using IBM SPSS v24.

The results of the serial mediation analyses for work engagement and job satisfaction are presented in Tables 4 and 5 respectively. All five of our hypotheses are supported by the data. Both followers' personal identification and affect-based trust in their leader completely mediate the effects of perceived authentic leadership on followers' affective organizational commitment. Personal identification also partially mediates the effects of authentic leadership on respondent's affect-based trust in their leader. Lastly, followers' affective organizational commitment completely mediates the effects of both personal identification and affect-based trust on respondents' work engagement and job satisfaction. See Figure 1 for a path model of these relationships - the non-significant mediation pathways are suppressed for clarity. 
Table 1. Correlation analysis of latent study variables

\begin{tabular}{|c|c|c|c|c|c|c|c|c|c|}
\hline Variable & Mean & SD & 1 & 2 & 3 & 4 & 5 & 6 & 7 \\
\hline 1. Authentic leadership & 4.69 & 1.32 & (.96) & & & & & & \\
\hline 2. Personal identification & 4.00 & 1.43 & $.72^{\star \star}$ & $(.93)$ & & & & & \\
\hline 3. Affect-based trust & 4.68 & 1.44 & $.67^{\star \star}$ & $.67^{\star \star}$ & $(.90)$ & & & & \\
\hline 4. Affective org. commit. & 4.25 & 1.30 & $.40^{\star \star}$ & $.55^{\star \star}$ & $.59^{\star \star}$ & $(.83)$ & & & \\
\hline 5. Work engagement & 4.68 & 1.13 & $.38^{\star \star}$ & $.46^{\star \star}$ & $.47^{\star \star}$ & $.61^{\star \star}$ & $(.85)$ & & \\
\hline 6. Job satisfaction & 4.85 & 1.33 & $.40^{\star \star}$ & $.41^{\star \star}$ & $.47^{\star \star}$ & $.60^{\star \star}$ & $.76^{\star \star}$ & $(.94)$ & \\
\hline 7. Social desirability & 5.60 & 1.22 & .08 & .04 & .04 & .07 & $.13^{*}$ & $.14^{\star}$ & (.95) \\
\hline
\end{tabular}

Note. $N=281$.

Coefficient alphas are in brackets on the diagonal.

${ }^{\star} p<0.05,{ }^{* *} p<0.01$.

Table 2. Reliability and validity analysis of study scales

\begin{tabular}{|c|c|c|c|c|c|c|c|c|c|c|}
\hline Variable & $\mathrm{CR}$ & AVE & MSV & 1 & 2 & 3 & 4 & 5 & 6 & 7 \\
\hline 1. Authentic leadership & 0.96 & 0.65 & 0.63 & 0.80 & & & & & & \\
\hline 2. Personal identification & 0.92 & 0.67 & 0.63 & 0.80 & 0.82 & & & & & \\
\hline 3. Affect-based trust & 0.89 & 0.67 & 0.57 & 0.76 & 0.75 & 0.82 & & & & \\
\hline 4. Affective org. commit. & 0.84 & 0.56 & 0.53 & 0.41 & 0.61 & 0.63 & 0.75 & & & \\
\hline 5. Work engagement & 0.83 & 0.56 & 0.77 & 0.42 & 0.52 & 0.48 & 0.73 & 0.75 & & \\
\hline 6. Job satisfaction & 0.94 & 0.79 & 0.77 & 0.40 & 0.45 & 0.51 & 0.65 & 0.88 & 0.89 & \\
\hline 7. Social desirability & 0.96 & 0.80 & 0.03 & 0.09 & 0.08 & 0.04 & 0.06 & 0.16 & 0.15 & 0.89 \\
\hline
\end{tabular}

Note. $N=281$.

Bold, italicized numbers denote Fornell and Larcker (1981) AVE test.

AVE, average variance extracted; CR, composite reliability; MSV, maximum shared variance.

These two models demonstrate strong predictive power by explaining a large portion of the variance for each of the three mediating mechanisms and the two outcome variables: personal identification $\left(R^{2}=.52, p<.001\right)$, affect-based trust $\left(R^{2}=.56, p<.001\right)$, affective organizational commitment $\left(R^{2}=.41, p<.001\right)$, work engagement $\left(R^{2}=.42, p<.001\right)$, and job satisfaction $\left(R^{2}=.41, p<.001\right)$. In the presence of these three mediating mechanisms, no direct effects from authentic leadership are observed on either of the two outcome variables. However, followers' perceptions of authentic leadership had a significant total indirect effect on both their work engagement $(\beta=.29, p<.05)$ and job satisfaction $(\beta=.25, p<.05)$, thus supporting our sequential mediation model of authentic leadership efficacy.

Having established the mediation model structure, we followed the robust research guidelines set out by Meyer, van Witteloostuijn, and Beugelsdijk (2017) and proceeded to reassess our hypotheses using an alternate method - structural equation modelling. The SEM approach allowed us to covary respondents' work engagement and job satisfaction, including them simultaneously as two related outcome variables. Following Carlson and $\mathrm{Wu}$ (2012), no control variables are included in the SEM model to determine whether or not the relations observed in the previous mediation analysis are artifacts of statistical controls (for a review, see Spector \& Brannick, 2011). The results indicate that the six factor path model established previously fit the data well $\left(\chi^{2} / d f(503)=1.80, p=.00, \mathrm{GFI}=.84 ; \mathrm{CFI}=.95 ; \mathrm{NFI}=.90 ; \mathrm{RMSEA}=.05\right)$. See Appendix $\mathrm{B}$ for a graphical representation of this path model and the beta coefficients. These 
Table 3. Results of nested model comparison

\begin{tabular}{|c|c|c|c|c|c|c|c|}
\hline Model & $\chi^{2}(d f)$ & $\chi^{2} / d f$ & GFI & $\mathrm{CFI}$ & $\mathrm{NFI}$ & RMSEA & $\begin{array}{l}\Delta \chi^{2} \text { from } \\
7 \text {-f. model }\end{array}$ \\
\hline $\begin{array}{l}\text { 7-factor model } \\
\quad(A L, P I, A B T, A O C, S D, J S, W E)\end{array}$ & $1,170.77(702)$ & 1.67 & .83 & .96 & .90 & .05 & Hypothesized model \\
\hline $\begin{array}{l}\text { 6-factor model } \\
\quad(A L, P I, A B T, A O C, S D \text {, and JS + WE) }\end{array}$ & $1,258.31(708)$ & 1.78 & .81 & .95 & .89 & .05 & $87.54^{\star \star \star}(d f 6)$ \\
\hline $\begin{array}{l}\text { 5-factor model } \\
\qquad(A L, P I, A B T, A O C \text {, and } S D+J S+W E)\end{array}$ & $2,801.37(713)$ & 3.93 & .64 & .80 & .75 & .10 & $1,630.60^{\star \star *}(d f 11)$ \\
\hline $\begin{array}{l}\text { 4-factor model } \\
\qquad(A L, P I, A B T \text {, and } A O C+S D+J S+W E)\end{array}$ & $3,047.23(717)$ & 4.25 & .61 & .78 & .73 & .11 & $1,876.46^{\star \star \star}(d f 15)$ \\
\hline $\begin{array}{l}\text { 3-factor model } \\
\qquad(A L, P I, \text { and } A B T+A O C+S D+J S+W E)\end{array}$ & $3,563.50(720)$ & 4.95 & .56 & .73 & .68 & .12 & $2,392.73^{\star * *}(d f 18)$ \\
\hline $\begin{array}{l}\text { 2-factor model } \\
\qquad(A L \text {, and } \mathrm{PI}+\mathrm{ABT}+\mathrm{AOC}+\mathrm{SD}+\mathrm{JS}+\mathrm{WE})\end{array}$ & $4,347.79(722)$ & 6.02 & .47 & .65 & .61 & .13 & $3,177.02^{\star \star \star}(d f 20)$ \\
\hline $\begin{array}{l}\text { 1-factor model } \\
\quad(A L+P I+A B T+A O C+S D+J S+W E)\end{array}$ & $4,950.31(723)$ & 6.85 & .42 & .59 & .56 & .15 & $3,779.54^{\star \star \star}(d f 21)$ \\
\hline
\end{tabular}

Note. $N=281$.

ABT, affect-based trust; AL, authentic leadership; AOC, affective organizational commitment; JS, job satisfaction; PI, personal identification; SD, social desirability; WE, work engagement.

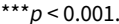

Table 4. Serial multiple mediation analysis of authentic leadership on work engagement

\begin{tabular}{|c|c|c|c|c|c|c|c|c|c|c|c|c|c|c|}
\hline \multirow{3}{*}{$\begin{array}{l}\text { Model } 1 \\
\text { Predictor } \\
\text { Industry }\end{array}$} & \multicolumn{3}{|c|}{ M1 - Personal ident. } & \multicolumn{4}{|c|}{ M2 - Affective trust } & \multicolumn{3}{|c|}{ M3 - Affective com. } & \multicolumn{4}{|c|}{ DV1 - Work engage. } \\
\hline & \multirow{2}{*}{$\begin{array}{c}\beta \\
.02\end{array}$} & \multirow{2}{*}{$\begin{array}{l}\text { SE } \\
.02\end{array}$} & $95 \% \mathrm{Cl}$ & \multirow{2}{*}{$\frac{\beta}{.06^{\star}}$} & \multirow{2}{*}{$\begin{array}{r}\text { SE } \\
.02\end{array}$} & \multicolumn{2}{|c|}{$95 \% \mathrm{Cl}$} & \multirow{2}{*}{$\begin{array}{c}\beta \\
.01\end{array}$} & \multirow{2}{*}{$\begin{array}{l}\text { SE } \\
.02\end{array}$} & $95 \% \mathrm{Cl}$ & \multirow{2}{*}{$\frac{\beta}{-.01}$} & \multirow{2}{*}{$\frac{\mathrm{SE}}{.02}$} & \multicolumn{2}{|c|}{$95 \% \mathrm{Cl}$} \\
\hline & & & $-.02 \quad .06$ & & & .02 & .10 & & & $-.04 \quad .05$ & & & -.04 & .03 \\
\hline Employment status & -.14 & .10 & $-.32 \quad .05$ & -.11 & .09 & -.29 & .07 & -.10 & .10 & $-.29 \quad .09$ & .11 & .08 & -.06 & .27 \\
\hline Organization size & -.00 & .08 & $-.17 \quad .16$ & $-.19^{\star}$ & .08 & -.35 & -.03 & -.06 & .09 & $-.22 \quad .11$ & -.08 & .07 & -.23 & .06 \\
\hline Supervisor tenure & $.03^{\star}$ & .02 & $.00 \quad .06$ & .02 & .02 & -.01 & .05 & .03 & .02 & $-.01 \quad .06$ & -.02 & .01 & -.05 & .01 \\
\hline Social desirability & -.06 & .06 & $-.18 \quad .06$ & .03 & .06 & -.08 & .15 & .03 & .06 & $-.08 \quad .15$ & $.13^{\star}$ & .05 & .03 & .23 \\
\hline IV - Authentic leadership & $.78^{\star \star}$ & .05 & $.69 \quad .87$ & $.46^{\star \star}$ & .06 & .33 & .58 & -.13 & .07 & $-.28 \quad .01$ & .03 & .06 & -.10 & .15 \\
\hline$M_{1}-$ Personal identification & & & & $.36^{\star \star}$ & .06 & .24 & .47 & $.32^{\star \star}$ & .07 & $.19 \quad .45$ & .10 & .06 & -.02 & .21 \\
\hline$M_{2}-$ Affect-based trust & & & & & & & & $.38^{\star \star}$ & .06 & $.26 \quad .51$ & .06 & .06 & -.06 & .17 \\
\hline$M_{3}$ - Affective org. commit. & & & & & & & & & & & $.43^{\star \star}$ & .05 & .33 & .53 \\
\hline Total indirect effect & & & & & & & & & & & $.29^{\star}$ & .06 & .16 & .41 \\
\hline Model summary & $\begin{array}{l}R^{2}= \\
F(6,\end{array}$ & $\begin{array}{l}.52, \\
274)\end{array}$ & $\begin{array}{l}0<.001 \\
=50.11\end{array}$ & & $\begin{array}{l}=.56 \\
273\end{array}$ & $\begin{array}{l}p<.00 \\
=49.3\end{array}$ & & $\begin{array}{l}R^{2}= \\
F(8,\end{array}$ & $\begin{array}{l}.41, p \\
272)\end{array}$ & $\begin{array}{l}p<.001 \\
=23.67\end{array}$ & $\begin{array}{l}R^{2}= \\
F(9,\end{array}$ & $\begin{array}{l}.42, p \\
271)\end{array}$ & $\begin{array}{l}0<.001 \\
=21.81\end{array}$ & \\
\hline
\end{tabular}

Note. $N=281$.

${ }^{\star} p<.05,{ }^{\star \star} p<.001$.

findings substantiate the results of our serial mediation analyses and add further support for our hypotheses.

These results also corroborate the findings of Wong, Spence-Laschinger, and Cummings (2010) that followers' personal identification and trust are the two primary mediators that function to deliver the positive outcomes of authentic leadership. We contribute to this stream of research by adding affective organizational commitment as the third major mediating 
Table 5. Serial multiple mediation analysis of authentic leadership on job satisfaction

\begin{tabular}{|c|c|c|c|c|c|c|c|c|c|c|c|c|c|}
\hline \multirow{3}{*}{$\begin{array}{l}\text { Model } 2 \\
\text { Predictor } \\
\text { Industry }\end{array}$} & \multicolumn{3}{|c|}{ M1 - Personal ident. } & \multicolumn{4}{|c|}{ M2 - Affective trust } & \multicolumn{3}{|c|}{ M3 - Affective com. } & \multicolumn{3}{|c|}{ DV2 - Job satisfaction } \\
\hline & \multirow{2}{*}{$\begin{array}{c}\beta \\
.02\end{array}$} & \multirow{2}{*}{$\begin{array}{l}\text { SE } \\
.02\end{array}$} & $95 \% \mathrm{Cl}$ & \multirow{2}{*}{$\frac{\beta}{.06^{\star}}$} & \multirow{2}{*}{$\begin{array}{l}\text { SE } \\
.02\end{array}$} & \multicolumn{2}{|c|}{$95 \% \mathrm{Cl}$} & \multirow{2}{*}{$\frac{\beta}{.01}$} & \multirow{2}{*}{$\begin{array}{l}\text { SE } \\
.02\end{array}$} & $95 \% \mathrm{Cl}$ & \multirow{2}{*}{$\frac{\beta}{-.02}$} & \multirow{2}{*}{$\begin{array}{l}\text { SE } \\
.02\end{array}$} & $95 \% \mathrm{Cl}$ \\
\hline & & & $-.02 \quad .06$ & & & .02 & .10 & & & $-.04 \quad .05$ & & & $\begin{array}{ll}-.06 & .0\end{array}$ \\
\hline Employment status & -.14 & .10 & $\begin{array}{ll}-.32 & .05\end{array}$ & -.11 & .09 & -.29 & .07 & -.10 & .10 & $-.29 \quad .09$ & $.22^{\star}$ & .10 & $.02 \quad .4$ \\
\hline Organization size & -.00 & .08 & -.17 .16 & $-.19^{\star}$ & .08 & -.35 & -.03 & -.06 & .09 & -.22 .11 & -.05 & .09 & -.22 .1 \\
\hline Supervisor tenure & $.03^{\star}$ & .02 & $.00 \quad .06$ & .02 & .02 & -.01 & .05 & .03 & .02 & $-.01 \quad .06$ & .00 & .02 & $-.03 \quad .0$ \\
\hline Social desirability & -.06 & .06 & $-.18 \quad .06$ & .03 & .06 & -.08 & .15 & .03 & .06 & $-.08 \quad .15$ & $.13^{\star}$ & .06 & $.01 \quad .2$ \\
\hline IV - Authentic leadership & $.78^{\star \star}$ & .05 & $.69 \quad .87$ & $.46^{\star \star}$ & .06 & .33 & .58 & -.13 & .07 & $\begin{array}{ll}-.28 & .01\end{array}$ & .14 & .07 & $-.01 \quad .2$ \\
\hline$M_{1}$ - Personal identification & & & & $.36^{\star \star}$ & .06 & .24 & .47 & $.32^{\star \star}$ & .07 & $.19 \quad .45$ & -.04 & .07 & -.17 .1 \\
\hline$M_{2}$ - Affect-based trust & & & & & & & & $.38^{\star \star}$ & .06 & $.26 \quad .51$ & .10 & .07 & $-.03 \quad .2$ \\
\hline$M_{3}$ - Affective org. commit. & & & & & & & & & & & $.50^{\star \star}$ & .06 & $.38 \quad .6$ \\
\hline Total indirect effect & & & & & & & & & & & $.25^{\star}$ & .08 & $.10 \quad .4$ \\
\hline Model summary & $\begin{array}{l}R^{2}= \\
F(6,\end{array}$ & & $\begin{array}{l}0<.001 \\
=50.11\end{array}$ & & $\begin{array}{l}.56, \\
273)\end{array}$ & $\begin{array}{l}p<.00 \\
=49.3\end{array}$ & & & $\begin{array}{l}.41, f \\
272)\end{array}$ & $\begin{array}{l}0<.001 \\
=23.67\end{array}$ & & $\begin{array}{l}.41, f \\
271)\end{array}$ & $\begin{array}{l}<.001 \\
=21.18\end{array}$ \\
\hline
\end{tabular}

Note. $N=281$.

${ }^{\star} p<.05,{ }^{\star *} p<.001$.

mechanism. Followers' work engagement and job satisfaction are frequently touted as important direct outcomes of authentic leadership (Banks et al., 2016; Hoch et al., 2018) - however, in the presence of the three mediators these direct relationships become non-significant. Indeed, our SEM model shows that followers' affective organizational commitment is the sole predictor of their work engagement $(\beta=.76, p<.01)$ and job satisfaction $(\beta=.70, p<.01)$, completely mediating the effects of both personal identification and affect-based trust.

\section{Discussion}

The present work advances our understanding of authentic leadership by modeling the mediation paths by which authentic leadership engenders positive follower outcomes. Authentic leadership positively influences followers' work engagement and job satisfaction through a sequential process of personal identification, affect-based trust, and affective organizational commitment.

The results suggest that followers who consider their supervisors to be authentic leaders experience positive work-related outcomes. In particular, we found that they were more satisfied with their jobs, more engaged at work, and more committed to the organization as a whole. These findings are congruent with recent empirical research (Giallonardo, Wong, \& Iwasiw, 2010; Jensen \& Luthans, 2006; Peus et al., 2012; Walumbwa et al., 2008; Wong, Spence-Laschinger, \& Cummings, 2010) and further support the utility of authentic leadership in the business sphere. Our results also support recent contributions in the literature that position followers' personal identification with their leader and their affect-based trust as the two primary mediators of authentic leadership efficacy (see Clapp-Smith, Vogelgesang, \& Avey, 2009; Giallonardo, Wong, \& Iwasiw, 2010; Wong, Spence-Laschinger, \& Cummings, 2010).

We advance work in this field by adding followers' affective organizational commitment as a major mediating mechanism. Consistent with our theoretical framework, authentic leadership delivered positive employee outcomes through three sequentially mediating mechanisms: personal identification, affect-based trust, and affective organizational commitment. Affective commitment is therefore at the core of the individual-level processes that transpire between followers' experience of authentic leadership behavior and their positive work-related outcomes. Employees' 
affective organizational commitment connects their personal identification and affect-based trust in with their work engagement and job satisfaction. This contribution to our understanding of authentic leadership processes comes from expanding the empirical investigation past the mechanisms of the individual relationships (e.g., trust and values identification) to the level of commitment to the wider organization.

The explanation of these results is straightforward: through the authentic leadership relationship followers come to trust and identify with their leader, which makes them actually want to come to work, and thus they become more satisfied and engaged. Personal identification in the present context is the process whereby individuals come to (re)define themselves in alignment with their leader's values. The candid, relationship-oriented approach of authentic leadership facilitates and encourages this personal identification process. As followers begin to personally identify with the authentic leader, they come to embrace the leader's values and goals as their own. According to social identity theory, leaders represent the organization and the resulting value-congruence thereby translates into increased affective organizational commitment, since the leaders are espousing values that the followers hold salient.

The results also suggest that as followers come to personally identify with their authentic leaders, they subsequently develop increased affect-based trust. A portion of the effect of authentic leadership on followers' trust occurs through the process of personal identification, wherein the followers' self-concept becomes derived from and congruent with that of the authentic leader. As employees come to know and personally identify with their leader, the leader's actions also make more sense and thereby produce increased trust: employees are more willing to make themselves vulnerable to authentic leaders with transparent goals and values. The combination of followers' shared values and authentic leaders' behavioral consistency creates a partial mediation effect as both sources contribute significantly to followers' increased trust in the leader. Employees who have such positive relationships with their leaders are also more likely to attach emotionally to the work environment through social identity theory, experiencing increased affective organizational commitment. Personal identification and affect-based trust are therefore two primary interconnected mechanisms through which authentic leadership improves followers' work-related outcomes.

The pivotal role of employees' affective organizational commitment in our framework challenges the typical position of the construct as a dependent variable. Theoretical implications arise by reframing affective commitment as a key mediating mechanism rather than as a terminal outcome. Employees who become emotionally attached to their organization - who want to come to work - begin to experience positive work-related outcomes, such as increased organizational citizenship behavior, discretionary effort, resilience, and reduced turnover, absenteeism, bullying behavior. At a time when individual careers routinely span multiple organizations and scholars question whether the commitment is even desirable (cf. Klein, Molloy, \& Brinsfield, 2012), we demonstrate the true value of forming such positive emotional bonds with your workplace. Leadership research should therefore focus on ways to develop employees' affective commitment, as their emotional attachment to the organization may prove to be more important than the work itself, their remuneration, or the workplace culture. Moreover, our serial mediation model shows that positive leader-follower relationships are the key to developing employees' organizational commitment.

\section{Practical implications}

Building self-awareness and authenticity are lifetime pursuits (Erickson, 1995; Gardner et al., 2005; Heidegger, 1962; Sartre, 1943). The present study highlights the central role of forming follower relationships characterized by shared identity and mutual trust. Developing an authentic leadership approach requires a substantial investment of leaders' two most valuable resources: energy and time. The results, however, are well worth the effort. Our findings are congruent 
with prior research (Banks et al., 2016) and confirm that authentic leadership delivers quantifiable increases across key employee metrics, including work engagement and job satisfaction, which serve as proxies for performance. Moreover, we identify followers' affective organizational commitment as the mechanism at the heart of authentic leadership: employees who have authentic leaders tend to want to come to work.

Engaged, satisfied employees, who want to come to work because they trust and identify with their leader, build enduring organizations and create lasting shareholder value (George, 2003). Managers who can foster strong emotional bonds between their employees and the organization - by developing trusting relationships and shared values - will improve their employees' performance. Organizations can therefore improve their overall productivity by recruiting and selecting managers who demonstrate authentic leadership behavior, and by offering organizational training and development that helps existing managers to cultivate an authentic approach. The first rule of business is to stay in business and those visionaries who are willing to invest in authentic leadership will ultimately surpass their myopic competitors.

\section{Limitations}

The present research has limitations. First, the data in this study are from a single high wealth country according to Grimm, Heise, Holzhausen, \& Romero (2019, p. 123), which suggests that the results may not generalize to medium or low wealth countries. The sample also encompasses a range of industries, cities, and firms; although this sampling strategy gives our findings wider generalizability, it may also prevent us from capturing subtleties that could exist within regions, ethnicities, and work groups. Without testing the wider context within which leadership occurs, we cannot estimate the effects of cross-level interactions: for instance, workers in precarious occupations may employ coping strategies that actively reduce their affective organizational commitment to mitigate psychological strain. By capturing a broad selection of industries, we estimate mean effects across most business contexts, and subsequent studies may seek to narrow the scope to explore between-group differences.

Second, this research does not capture respondents' individual differences beyond simple demographic information, some of which may also alter the pattern of results. For example, respondents' cultural values, such as power distance, could attenuate or intensify the observed relations by interacting with their perceptions of authentic leadership - which are culturally embedded (Iszatt-White \& Kempster, 2018). Since the literature now broadly accepts that culture should be measured at the individual level, rather than assigned at the country level, such hypotheses could be investigated within single-country samples (cf. Beugelsdijk, Kostova, \& Roth, 2017; Kirkman, Lowe, \& Gibson, 2017). These arguments may be extended to a host of other individual-level differences and future researchers could investigate moderated mediation models to study their effects on the processes that connect authentic leadership to desirable follower outcomes.

The third limitation regards the issue of causality. The present design cannot establish whether employees' affective organizational commitment leads to increased job satisfaction, or if satisfied employees only then begin to develop an emotional attachment to their organization. However, we provide sound theoretical arguments for the sequence of mediated effects, which inform the causal structure of our model and are corroborated by the data; indeed, a simple re-arrangement of the variables yields no other viable model with acceptable fit properties. Similarly, we cannot estimate the effects of employees' positive leader-directed affect on their responses (Martinko, Mackey, Moss, Harvey, McAllister, \& Brees, 2018), or what effects the present processes may have on other unexamined variables of consequence. For example, Kark, Shamir, and Chen (2003) find in their investigation of transformational leadership that personal identification may also have a darker side: increasing followers' dependence on the leader, rather than their empowerment. 


\section{Future research}

Future streams of authentic leadership research could explore longitudinal designs and field experiments to establish the causality of mediated effects. Business leadership training, interventions, seminars, or retreats could serve as suitable contexts for an experimental research design, where survey data is collected before and after for direct comparison. The control group can receive the same leadership training after the study has been completed so as to not disadvantage any one group of participants. The present stream of research may also benefit from a multi-level design to explore whether positive leadership forms may create a climate of affective organizational commitment comprised of multiple mutually-reinforcing actors that generates desirable work-related outcomes. Similar study designs abound in ethical leadership climate research and could be adapted to suit the present context. Future scholars may also consider what moderating variables alter the nature of relations between followers' affective organizational commitment and its various antecedents to explore under what conditions positive leadership forms produce increased commitment.

\section{Conclusion}

The present work offers significant advances to authentic leadership research and the results have meaningful implications for academics and practitioners alike. By identifying the three mediating mechanisms of authentic leadership we contextualize its operation with important organizational processes and outcomes. In particular, we extend existing research on the relational mediators of authentic leadership by connecting them to desirable follower outcomes. In doing so, we challenge traditional notions of commitment that position it as a terminal variable: instead, we demonstrate how followers' affective organizational commitment mediates authentic leadership efficacy and operates as an antecedent of positive work-related outcomes. Thus we contribute to ongoing authentic leadership research by untangling some of the complex processes at work behind the ephemeral construct.

\section{References}

Alilyyani, B., Wong, C. A., \& Cummings, G. G. (2018). Antecedents, mediators, and outcomes of authentic leadership in healthcare: A systematic review. International Journal of Nursing Studies, 83, 34-64.

Allen, N. J., \& Meyer, J. P. (1990). The measurement and antecedents of affective, continuance and normative commitment to the organization. Journal of Occupational Psychology, 63, 1-18.

Ashforth, B. E., Schinoff, B. S., \& Rogers, K. M. (2016). "I identify with her," "I identify with him": Unpacking the dynamics of personal identification in organizations. Academy of Management Review, 41, 28-60.

Ashkanasy, N. M. (2008). Submitting your manuscript. Journal of Organizational Behavior, 29, 263-264.

Avolio, B. J., \& Gardner, W. L. (2005). Authentic leadership development: Getting to the root of positive forms of leadership. The Leadership Quarterly, 16, 315-338.

Avolio, B. J., Walumbwa, F. O., \& Weber, T. J. (2009). Leadership: Current theories, research and future directions. Annual Review of Psychology, 60, 421-449.

Banks, G. C., McCauley, K. D., Gardner, W. L., \& Guler, C. E. (2016). A meta-analytic review of authentic and transformational leadership: A test for redundancy. The Leadership Quarterly, 27, 634-652.

Becker, T. E. (2005). Potential problems in the statistical control of variables in organizational research: A qualitative analysis with recommendations. Organizational Research Methods, 8, 274-289.

Beugelsdijk, S., Kostova, T., \& Roth, K. (2017). An overview of Hofstede-inspired country-level culture research in international business since 2006. Journal of International Business Studies, 48, 30-47.

Brewer, M. B., \& Gardner, W. (1996). Who is this "We"? levels of collective identity and self representations. Journal of Personality and Social Psychology, 71, 83.

Buchanan, B. (1974). Building organizational commitment: The socialization of managers in work organizations. Administrative Science Quarterly, 19, 533-546.

Butler, J. K. (1991). Toward understanding and measuring conditions of trust: Evolution of a conditions of trust inventory. Journal of Management, 17, 643-663. 
Campbell, J. D., Trapnell, P. D., Heine, S. J., Katz, I. M., Lavallee, L. F., \& Lehman, D. R. (1996). Self-concept clarity: Measurement, personality correlates, and cultural boundaries. Journal of Personality and Social Psychology, 70, 141-156.

Carlson, K. D., \& Wu, J. (2012). The illusion of statistical control: Control variable practice in management research. Organizational Research Methods, 15, 413-435.

Clapp-Smith, R., Vogelgesang, G. R., \& Avey, J. B. (2009). Authentic leadership and positive psychological capital: The mediating role of trust at the group level of analysis. Journal of Leadership \& Organizational Studies, 15, 227-240.

Colquitt, J. A., Baer, M. D., Long, D. M., \& Halvorsen-Ganepola, M. D. K. (2014). Scale indicators of social exchange relationships: A comparison of relative content validity. Journal of Applied Psychology, 99, 599-618.

Conway, J. M., \& Lance, C. E. (2010). What reviewers should expect from authors regarding common method bias in organizational research. Journal of Business Psychology, 25, 325-334.

DeVellis, R. F. (2012). In L. Bickman \& D. J. Rog (Eds.), Scale development: Theory and applications (3rd ed.). Thousand Oaks, CA: Sage.

Dirks, K. T., \& Ferrin, D. L. (2002). Trust in leadership: Meta-analytic findings and implications for research and practice. Journal of Applied Psychology, 87, 611-628.

Erickson, R. J. (1995). The importance of authenticity for self and society. Symbolic Interaction, 18, 121-144.

Fornell, C., \& Larcker, D. F. (1981). Evaluating structural equation models with unobserved variables and measurement error. Journal of Marketing Research, 18, 39-50.

Fox, J. T., Gong, T., \& Attoh, P. (2015). The impact of principal as authentic leader on teacher trust in the K-12 educational context. Journal of Leadership Studies, 8, 6-18.

Fritz, M. S., \& MacKinnon, D. P. (2007). Required sample size to detect the mediated effect. Psychological Science, 18, $233-239$.

Gardner, W. L., Avolio, B. J., Luthans, F., May, D. R., \& Walumbwa, F. O. (2005). “Can you see the real me?” A self-based model of authentic leader and follower development. The Leadership Quarterly, 16, 343-372.

Gardner, W. L., Cogliser, C. C., Davis, K. M., \& Dickens, M. P. (2011). Authentic leadership: A review of the literature and research agenda. The Leadership Quarterly, 22, 1120-1145.

George, B. (2003). Authentic leadership: Rediscovering the secrets to creating lasting value. San Francisco, CA: Jossey-Bass.

Giallonardo, L. M., Wong, C. A., \& Iwasiw, C. L. (2010). Authentic leadership of preceptors: Predictor of new graduate nurses' work engagement and job satisfaction. Journal of Nursing Management, 18, 993-1003.

Grimm, M., Heise, M., Holzhausen, A., \& Romero, P. P. (2019). In H. Bähr \& L. Weimann (Eds.), Allianz global wealth report 2019. Munich, Germany: Allianz SE.

Grint, K., Jones, O. S., \& Holt, C. (2017). What is leadership: Person, result, position or process, or all or none of these? In J. Storey, H. Jean, J.-L. Denis, P. T. Hart \& D. Ulrich (Eds.), The routledge companion to leadership (pp. 3-20). New York, NY: Routledge.

Hair, J. F., Black, W. C., Babin, B. J., \& Anderson, R. E. (2010). Multivariate data analysis (7th ed.). Upper Saddle River, NJ: Prentice-Hall.

Hasel, M. C., \& Grover, S. L. (2017). An integrative model of trust and leadership. Leadership and Organization Development Journal, 38, 849-867.

Hayes, A. F. (2013). In D. A. Kenny (Ed.), Introduction to mediation, moderation, and conditional process analysis: A regression-based approach. New York, NY: The Guilford Press.

Heidegger, M. (1962). In J. Macquarrie \& E. S. Robinson (Eds.), Being and time. New York, NY: Harper and Row.

Hinkin, T. R. (1995). A review of scale development practices in the study of organizations. Journal of Management, 21, 967-988.

Hinkin, T. R., \& Tracey, J. B. (1999). An analysis of variance approach to content validation. Organizational Research Methods, 2, 175-186.

Hoch, J. E., Bommer, W. H., Dulebohn, J. H., \& Wu, D. (2018). Do ethical, authentic, and servant leadership explain variance above and beyond transformational leadership? A meta-analysis. Journal of Management, 44, 501-529.

Hooijberg, R., \& Choi, J. (2001). The impact of organizational characteristics on leadership effectiveness models: An examination of leadership in a private and a public sector organization. Administration \& Society, 33, 403-431.

Howell, J. M., \& Shamir, B. (2005). The role of followers in the charismatic leadership process: Relationships and their consequences. Academy of Management Review, 30, 96-112.

Iszatt-White, M., \& Kempster, S. (2018). Authentic leadership: Getting back to the roots of the 'root construct'? International Journal of Management Reviews, 00, 1-14. doi: https://doi.org/10.1111/ijmr.12193

Jensen, S. M., \& Luthans, F. (2006). Entrepreneurs as authentic leaders: Impact on employees' attitudes. Leadership \& Organization Development Journal, 27, 646-666.

Kalshoven, K., \& Den Hartog, D. N. (2009). Ethical leader behavior and leader effectiveness: The role of prototypicality and trust. International Journal of Leadership Studies, 5, 102-120.

Kark, R., \& Shamir, B. (2002). The dual effect of transformational leadership: Priming relational and collective selves and further effects on followers. In B. J. Avolio \& F. J. Yammarino (Eds.), Transformational and charismatic leadership: The road ahead (pp. 7-91). Oxford, UK: Elsevier.

Kark, R., Shamir, B., \& Chen, G. (2003). The two faces of transformational leadership: Empowerment and dependency. Journal of Applied Psychology, 88, 246-255. 
Katz, D. (1964). The motivational basis of organizational behavior. Behavioral Science, 9, 131-146.

Kirkman, B. L., Lowe, K. B., \& Gibson, C. B. (2017). A retrospective on culture's consequences: The 35-year journey. Journal of International Business Studies, 48, 12-29.

Klein, H. J., Molloy, J. C., \& Brinsfield, C. T. (2012). Reconceptualizing workplace commitment to redress a stretched construct: Revisiting assumptions and removing confounds. Academy of Management Review, 37, 130-151.

Koene, B. A. S., Vogelaar, A. L. W., \& Soeters, J. L. (2002). Leadership effects on organizational climate and financial performance: Local leadership effect in chain organizations. The Leadership Quarterly, 13, 193-215.

Mael, F., \& Ashforth, B. E. (1992). Alumni and their alma mater: A partial test of the reformulated model of organizational identification. Journal of Organizational Behavior, 13, 103-123.

Malhotra, N., \& Mukherjee, A. (2004). The relative influence of organisational commitment and job satisfaction on service quality of customer-contact employees in banking call centres. Journal of Services Marketing, 18, 162-174.

Martinko, M. J., Mackey, J. D., Moss, S. E., Harvey, P., McAllister, C. P., \& Brees, J. R. (2018). An exploration of the role of subordinate affect in leader evaluations. Journal of Applied Psychology, 103, 738.

Mayer, R., Davis, J., \& Schoorman, F. (1995). An integration model of organizational trust. Academy of Management Review, 20, 709-729.

McAllister, D. J. (1995). Affect- and cognition-based trust as foundations for interpersonal cooperation in organizations. Academy of Management Journal, 38, 24-59.

McGee, G. W., \& Ford, R. C. (1987). Two (or more?) dimensions of organizational commitment: Reexamination of the affective and continuance commitment scales. Journal of Applied Psychology, 72, 638-641.

Meyer, J. P., \& Allen, N. J. (1984). Testing the "side bet theory" of organizational commitment: Some methodological considerations. Journal of Applied Psychology, 69, 372-378.

Meyer, J. P., \& Allen, N. J. (1991). A three-component conceptualization of organizational commitment. Human Resource Management Review, 1, 61-89.

Meyer, J. P., Allen, N. J., \& Gellatly, I. R. (1990). Affective and continuance commitment to the organization: Evaluation of measures and analysis of concurrent and time-lagged relations. Journal of Applied Psychology, 75, 710-720.

Meyer, J. P., Paunonen, S. V., Gellatly, I. R., Goffin, R. D., \& Jackson, D. N. (1989). Organizational commitment and job performance: It's the nature of the commitment that counts. Journal of Applied Psychology, 74, 152-156.

Meyer, J. P., Stanley, D. J., Herscovitch, L., \& Topolnytsky, L. (2002). Affective, continuance, and normative commitment to the organization: A meta-analysis of antecedents, correlates, and consequences. Journal of Vocational Behavior, 61, 20-52.

Meyer, K. E., van Witteloostuijn, A., \& Beugelsdijk, S. (2017). What's in a $p$ ? Reassessing best practices for conducting and reporting hypothesis-testing research. Journal of International Business Studies, 48, 535-551.

Neider, L. L., \& Schriesheim, C. A. (2011). The authentic leadership inventory (ALI): Development and empirical tests. The Leadership Quarterly, 22, 1146-1164.

Nunnally, J. (1978). Psychometric theory (2nd ed.). New York, NJ: McGraw-Hill.

Nyhan, R. C. (1999). Increasing affective organizational commitment in public organizations: The key role of interpersonal trust. Review of Public Personnel Administration, 19, 58-70.

Nyhan, R. C., \& Marlowe, H. A. (1997). Development and psychometric properties of the organizational trust inventory. Evaluation Review, 21, 614-635.

O’Connor, E. J., Peters, L. H., \& Gordon, S. M. (1978). The measurement of job satisfaction: Current practices and future considerations. Journal of Management, 4, 17-26.

Organ, D. W., Podsakoff, P. M., \& MacKenzie, S. B. (2005). In A. S. Huff, B. Schneider \& M. S. Taylor (Eds.), Organizational citizenship behavior: Its nature, antecedents, and consequences. Thousand Oaks, CA: Sage.

Perry, R. W. (2004). The relationship of affective organizational commitment with supervisory trust. Review of Public Personnel Administration, 24, 133-149.

Peterlin, J., Penger, S., \& Dimovski, V. (2009). Authentic leadership as the promising link between western and eastern management practices: The case of Slovenian company. International Business \& Economics Research Journal, 8, 87-98.

Peus, C., Wesche, J. S., Streicher, B., Braun, S., \& Frey, D. (2012). Authentic leadership: An empirical test of its antecedents, consequences, and mediating mechanisms. Journal of Business Ethics, 107, 331-348.

Podsakoff, P. M., MacKenzie, S. B., Lee, J.-Y., \& Podsakoff, N. P. (2003). Common method biases in behavioral research: A critical review of the literature and recommended remedies. Journal of Applied Psychology, 88, 879-903.

Poon, J. M. L. (2013). Relationships among perceived career support, affective commitment, and work engagement. International Journal of Psychology, 48, 1148-1155.

Preacher, K. J., \& Hayes, A. F. (2004). SPSS and SAS procedures for estimating indirect effects in simple mediation models. Behavior Research Methods, Instruments, \& Computers, 36, 717-731.

Pugh, S. D., Groth, M., \& Hennig-Thurau, T. (2011). Willing and able to fake emotions: A closer examination of the link between emotional dissonance and employee well-being. Journal of Applied Psychology, 96, 377-390.

Reynolds, W. M. (1982). Development of reliable and valid short forms of the Marlowe-Crowne social desirability scale. Journal of Clinical Psychology, 38, 119-125. 
Ribisl, K. M., Walton, M. A., Mowbray, C. T., Luke, D. A., Davidson, W. S., \& Bootsmiller, B. J. (1996). Minimizing participant attrition in panel studies through the use of effective retention and tracking strategies: Review and recommendations. Evaluation and Program Planning, 19, 1-25.

Richardson, H. A., Simmering, M. J., \& Sturman, M. C. (2009). A tale of three perspectives: Examining post hoc statistical techniques for detection and correction of common method variance. Organizational Research Methods, 12, 762-800.

Robinson, S. L. (1996). Trust and breach of the psychological contract. Administrative Science Quarterly, 41, 574-599.

Rousseau, D. M., Sitkin, S. B., Burt, R. S., \& Camerer, C. (1998). Not so different after all: A cross-discipline view of trust. Academy of Management Review, 23, 393-404.

Sartre, J.-P. (1943). In H. E. Barnes (Ed.), Being and nothingness: An essay on phenomenological ontology. New York, NY: Washington Square Press.

Schaufeli, W. B., Bakker, A. B., \& Salanova, M. (2006). The measurement of work engagement with a short questionnaire: A cross-national study. Educational and Psychological Measurement, 66, 701-716.

Schriesheim, C. A., \& Cogliser, C. C. (2009). Construct validation in leadership research: Explication and illustration. The Leadership Quarterly, 20, 725-736.

Schriesheim, C. A., Cogliser, C. C., Scandura, T. A., Lankau, M. J., \& Powers, K. J. (1999). An empirical comparison of approaches for quantitatively assessing the content adequacy of paper-and-pencil measurement instruments. Organizational Research Methods, 2, 140-156.

Shamir, B., Zakay, E., Breinin, E., \& Popper, M. (1998). Correlates of charismatic leader behavior in military units: Subordinates' attitudes, unit characteristics, and superiors' appraisals of leader performance. Academy of Management Journal, 41, 387-409.

Shore, L. M., \& Wayne, S. J. (1993). Commitment and employee behavior: Comparison of affective commitment and continuance commitment with perceived organizational support. Journal of Applied Psychology, 78, 774-780.

Spector, P. E., \& Brannick, M. T. (2011). Methodological urban legends: The misuse of statistical control variables. Organizational Research Methods, 14, 287-305.

Tajfel, H., \& Turner, J. C. (1986). The social identify theory of intergroup behavior. In S. Worchel \& W. G. Austin (Eds.), Psychology of intergroup relations (2nd ed., pp. 7-24). Chicago, IL: Nelson-Hall.

Teo, S. T. T., Pick, D., Xerri, M., \& Newton, C. (2016). Person-organization fit and public service motivation in the context of change. Public Management Review, 18, 740-762.

Thompson, E. R., \& Phua, F. T. T. (2012). A brief index of affective job satisfaction. Group \& Organization Management, 37, 275-307.

Thorsteinson, T. J. (2003). Job attitudes of part-time vs. Full-time workers: A meta-analytic review. Journal of Occupational and Organizational Psychology, 76, 151-177.

Vaccaro, I. G., Jansen, J. J. P., Van Den Bosch, F. A. J., \& Volberda, H. W. (2012). Management innovation and leadership: The moderating role of organizational size. Journal of Management Studies, 49, 28-51.

Van Knippenberg, D. (2011). Embodying who we are: Leader group prototypicality and leadership effectiveness. The Leadership Quarterly, 22, 1078-1091.

Van de Mortel, T. F. (2008). Faking it: Social desirability response bias in self-report research. Australian Journal of Advanced Nursing, 25, 40.

Walumbwa, F. O., Avolio, B. J., Gardner, W. L., Wernsing, T. S., \& Peterson, S. J. (2008). Authentic leadership: Development and validation of a theory-based measure. Journal of Management, 34, 89-126.

Whitman, D. S., Van Rooy, D. L., \& Viswesvaran, C. (2010). Satisfaction, citizenship behaviors, and performance in work units: A meta-analysis of collective construct relations. Personnel Psychology, 63, 41-81.

Williams, L. J., \& Anderson, S. E. (1994). An alternative approach to method effects by using latent-variable models: Applications in organizational behavior research. Journal of Applied Psychology, 79, 323-331.

Williams, L. J., Edwards, J. R., \& Vandenberg, R. J. (2003). Recent advances in causal modeling methods for organizational and management research. Journal of Management, 29, 903-936.

Wolf, E. J., Harrington, K. M., Clark, S. L., \& Miller, M. W. (2013). Sample size requirements for structural equation models: An evaluation of power, bias, and solution propriety. Educational and Psychological Measurement, 73, 913-934.

Wong, C. A., \& Cummings, G. G. (2009). The influence of authentic leadership behaviors on trust and work outcomes of health care staff. Journal of Leadership Studies, 3, 6-23.

Wong, C. A., Spence-Laschinger, H. K., \& Cummings, G. G. (2010). Authentic leadership and nurses' voice behaviour and perceptions of care quality. Journal of Nursing Management, 18, 889-900. 


\section{Appendix A}

\section{Personal Identification with Leader Scale (PILS) Items}

\begin{tabular}{|c|c|c|c|}
\hline Items & Mean & SD & AIC \\
\hline 1. When someone criticises my supervisor, it feels like a personal insult. & 3.54 & 1.60 & .59 \\
\hline 2. I am very interested in what others think about my supervisor. & 4.07 & 1.52 & .29 \\
\hline 3. I view the success of my supervisor as my own success. & 3.68 & 1.66 & .54 \\
\hline 4. I am proud to tell others that he/she is my supervisor. & 4.40 & 1.61 & .64 \\
\hline $\begin{array}{l}\text { 5. I praise my supervisor, when speaking with friends, as someone who is good } \\
\text { to work for. }\end{array}$ & 4.58 & 1.64 & .64 \\
\hline 6. I highly identify with my supervisor. & 4.18 & 1.69 & .68 \\
\hline 7. It is important for me to see myself as an employee of my supervisor. & 3.75 & 1.64 & .58 \\
\hline 8. My supervisor is a role model for me. & 3.75 & 1.73 & .66 \\
\hline 9. The values of my supervisor are similar to my values. & 4.28 & 1.68 & .59 \\
\hline 10. I consider my supervisor as a symbol of success and achievement. & 4.04 & 1.70 & .65 \\
\hline
\end{tabular}

Note. $N=281$. AIC = Average Inter-item Correlation. Adapted from Kark, Shamir, and Chen (2003).

\section{Appendix B}

\section{Structural Equation Modelling Analysis of Authentic Leadership Processes}

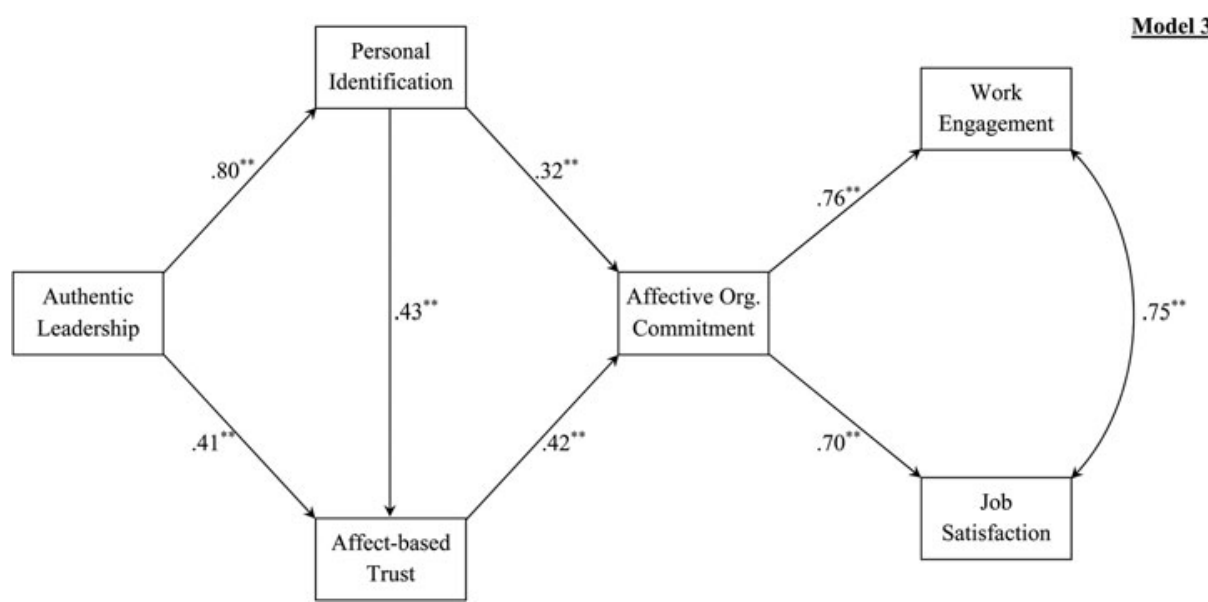

Note. $N=281,{ }^{*} p<.05,{ }^{*} p<.001$. Model fit indices: $\chi^{2} / d f(503)=1.80, p=.00, \mathrm{GFI}=.84 ; \mathrm{CFI}=.95 ; \mathrm{NFI}=.90 ; \mathrm{RMSEA}=.05$.

Cite this article: Lux AA, Grover SL, Teo STT (2023). Reframing commitment in authentic leadership: Untangling relationship-outcome processes. Journal of Management \& Organization 29, 103-121. https://doi.org/10.1017/jmo.2019.78 